\title{
Differences in the Assessment of Economic Security of Personnel and Security of Enterprise Staff Interests
}

\author{
MISHCHUK IEVGENIIA \\ Department of Accounting, Taxation, Public and Management and Administration \\ Kryvyi Rih National University \\ 11 Vitalyy Matusevych Str., Kryvyi Rih, 50027 \\ UKRAINE \\ https://orcid.org/0000-0003-4145-3711 \\ ZINCHENKO OLENA \\ Department of Finance business entities and innovation development \\ Kryvyi Rih National University \\ 11 Vitalyy Matusevych Str., Kryvyi Rih, 50027 \\ UKRAINE \\ https://orcid.org/0000-0003-1156-1148 \\ ZINCHENKO DMYTRO \\ Department of Economics and Entrepreneurship \\ Igor Sikorsky Kiev Polytechnic Institute \\ 37 Victory Avenue, Kiev, 03056 \\ UKRAINE \\ https://orcid.org/0000-0001-8674-5449 \\ DARIUSZ PAWLISZCZY \\ Mayor of city Gromadka \\ POLAND \\ https://orcid.org/0000-0003-1328-7891 \\ POHREBNIAK ANNA \\ Department of Economics and Entrepreneurship \\ Igor Sikorsky Kiev Polytechnic Institute \\ 37 Victory Avenue, Kiev, 03056 \\ UKRAINE \\ https://orcid.org/0000-0003-2421-476X
}

\begin{abstract}
Neglect of individual features of personnel security and enterprise staff interests security affects the adequacy of assessing the general level of economic security of an enterprise, of which they both are components. It is substantiated that a system of measures of personnel KPI and personnel provision are indicators of assessing an enterprise's staff interests. Security are a system of personnel interests of an enterprise are a system of performance indicators for KPI personnel and indicators of staffing and social benefits are indicators of economic security of the personnel. The article enhances the methodology for assessing staff interests security on the basis of calculating deficit of the earnings before tax amount which an enterprise can receive if its indicators do not reach their minimum necessary values. It is taken into account that underfunding of social programs is characterized by outstanding expenses of an enterprise the increase of which affects economic security of its personnel and intensifies the threats caused by them. Application of the suggested approach will contribute to a more effective control over the level of economic security and improve the analytical support of making managerial decisions of the financial and economic nature.
\end{abstract}

Key-Words: economic security, staff interests of an enterprise, income deficit, labour productivity, outstanding expenses, personnel.

Received: September 13, 2019. Revised: April 24, 2020. Accepted: May 19, 2020. Published: June 7, 2020 


\section{Introduction}

Most scholars studying economic security of enterprises suggest the security components that are connected with the personnel to this or that extent. It should be noted that the components are rather similar in their structure and content. Therefore, it is the most generalizing classification that is the subject of further detailed consideration. The work of this kind is presented in the monograph that deals with socio-environmental security within which such types of economic security as personnel, social, intellectual, environmental, physical and labor ones are singled out $[1$, p.27, 29, 182]. On the whole, the content of the mentioned components is reflected in their names and characterizes personnel provision, social protection of the personnel, development of the intellectual potential, environmental compliance, health care, protection of an enterprise's property and reputation. However, the division like that is not obvious. In particular, one should agree with the results in [2] that substantiate that influence of intellectual potential (in the context of human capital potential in general) on economic security of an enterprise as a separate factor but not its component. The intellectual potential is a wide concept consisting of individual components, which are sufficiently covered in [3; 4]. That is why, it is not dealt with in this article. Depending on the object of protection, it looks reasonable to refer security of enterprise property to either criminal security or security of economicproductive interests of an enterprise. As for the environmental component, the following should be noted. The authors of [1, p. 181] prove (by means of an example of the mining industry) that fines paid for violation of environmental and labor protection regulations are minor - the largest percentage of the monthly payroll makes $0.22 \%$. The above mentioned also actualizes change in architectonics of an enterprise's economic security through singling out the environmental component and referring it to security of stakeholders - employees and the community whose interests are essential while enhancing this very factor. Let us indicate that modern investigations tend to focus on the necessity to arrange personnel protection $[5 ; 6]$. At this, we can distinguish two groups of bipolar approaches. According to the first one, staff security and personnel security are considered separately (as in [5]) while the other one equates them or personnel security is identified as a subtype of staff security [6]. Let us clarify the following: when it comes to enterprise staff, it is expedient to speak about security of staff interests from the viewpoint of economic security of an enterprise (as a legal entity) without its stakeholders.

Thus, at the present stage of the security science, it is expedient to highlight separate investigations into economic security of staff interests of an enterprise and economic security of its personnel. The latter should take account of labour security and employees' health security, which used to be considered separately within the structure of labour security and physical security respectively.

\section{Problem Formulation}

The authors of [1, p. 29] have drawn an important conclusion about possible deterioration of economic indicators of an enterprise's activity when reaching social and economic security. However, besides, they have also expressed a debatable remark as to the absence of a direct connection between an enterprise's property and financial state and components of social and economic security. These both statements result in generating the issue of appropriate provision of this type of security in general and the necessity to distinguish it within the economic security structure in particular. While determining logicality of the authors' scientific developments [1], it should be noted that this issue seems insufficiently substantiated. The issue also remains neglected in other scholars' works. Besides, available unsolved issues of architectonics of economic security with economic security of staff interests and personnel security being singled out cause controversy and ambiguity of their assessment. In particular, based on investigations into modern systems of controlling personnel security, [6] focuses on psychological and behavioral characteristics of employees and introduction of modern modelling methods (Bayesian models, nonlinear models of recurrent neural networks, linear regression, K-mean algorithms) and presents methods of assessing an enterprise's economic security. To solve this problem, a stereometric approach is suggested [7]. Yet, its application is quite labour-consuming and seems inappropriate for express-assessment of personnel security. However, it is applicable to conducting an in-depth assessment of economic security of stakeholders and an enterprise itself. At the same time, it should be underlined that assessment of security of staff interests (staff 
security) is mostly based on separate coefficients of personnel movement or an integrated indicator which includes several similar coefficients. This approach also involves assumption of weak potential to assess the influence of non-achieving a particular level of this security type on economic outcomes of an enterprise's activity and its economic security as a result.

Thus, the article is aimed at improving methods of assessing economic security of an enterprise's personnel and security of its staff interests considering revealed differences between them

\section{Problem Solution}

Specific differentiation of the hierarchical structure of an enterprise's economic security with two security types identified by modern researchers personnel economic security and security of staff interests - implies protection-object heterogeneity accompanied by homogeneity of a threat source. In particular, personnel economic security and security of staff interests are characterized by essentially different objects of protection. In the former case, such objects include security interests of providing with required personnel according to all the criteria and security of efficient use of available personnel. In the latter case, this object is economic interests of the personnel. For both types of security, the personnel is a source of threat (Fig. 1).

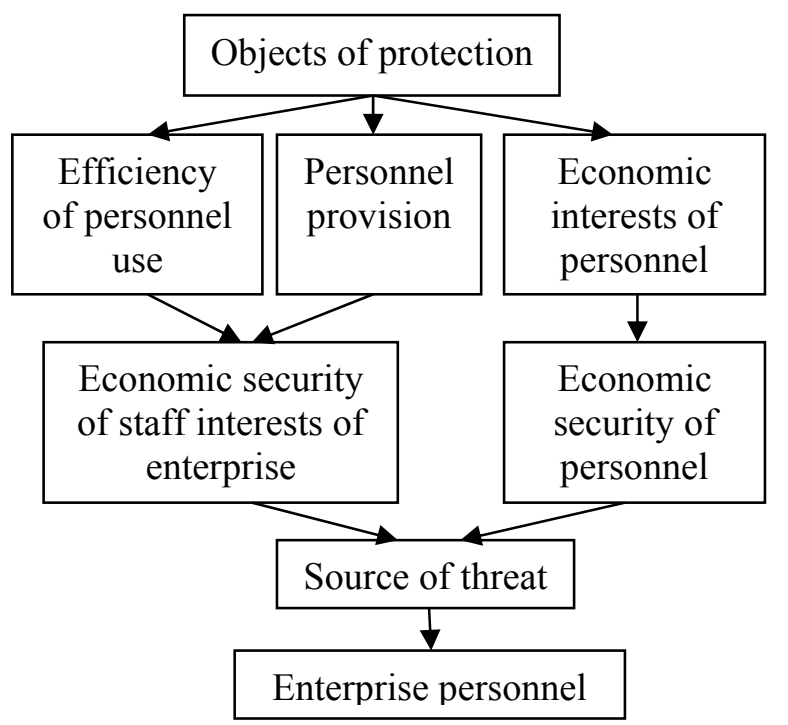

Fig. 1. Protection-object heterogeneity as a determinant for differentiating security of staff interests of an enterprise and economic security of the personnel (developed by the authors)

Efficiency of personnel use should be assessed by their contribution to total results of an enterprise's activity according to several directions: a company's increased incomes; development of new scientific trends, relations with clients; coordination of departments' activities; successful implementation of linear functions [8]. Yet, only the first contribution type can be assessed quantitatively while the others affect incomes of an enterprise indirectly. Considering this, we suggest assessing economic security of staff interests by means of EBT values, yet not absolute ones, but the deficit value resulting from inefficient use of available personnel and/or its poor provision. As to personnel economic security, it should be noted that its increase is a prerequisite of a greater involvement of employees and their loyalty to the enterprise. In its turn, increased involvement of employees causes increased economic security of an enterprise through improving its key economic indicators (Table 1).

It is essential that at the leading enterprises, the number of "involved" employees is $30 \%$ higher and, according to Gallup, reaches $90 \%$ [9]. The mentioned data indicate the mutual influence of the involvement level and economic results of an enterprise's activity including the level of its economic security.

In the modern world, reward for labour is not a single factor of personnel security any more. There are some trends towards increasing the retirement age in some countries and life expectancy in others that cause prolonged careers of workable people. In such conditions, employees require further personal and professional development. Enterprises offering opportunities of development gain some competitive advantages when filling their vacancies [10, p. 49], this fact improving security of staff interests. At the same time, the present-day system of personnel development provides for different types of training: correspondence, online, scheduled trainings, internships, teaching guides obtained from outside, experience exchange and formal training $[10 ; 11]$. Financing personnel training facilitates employees' skills and competences required for further development of an enterprise in general and improvement of its economic security in particular. According to Deloitte's investigations, the involvement level is $25 \%$ higher at those enterprises that offer opportunities to train on a continuous basis. Yet, besides training, leading companies also take some other steps to ensure personnel security (Table 2).

Thus, along with salaries, important indicators of providing personnel economic security include an enterprise's spending on financing social projects and development programmes. 
Table 1. Results of investigations into influence of changes in employees involvement on economic indicators of an enterprise's activity

\begin{tabular}{|c|c|c|}
\hline $\begin{array}{c}\text { Subject of } \\
\text { investigation }\end{array}$ & $\begin{array}{l}\text { Indicators influenced by } \\
\text { changes in involvement }\end{array}$ & Results of investigation \\
\hline Aon Hewitt & Income & $\begin{array}{l}\text { Involvement increased by } 1 \% \text { has caused increased income by } \\
\$ 20 \mathrm{mln} \text {, that by } 5 \%-100 \mathrm{mln} \text { and by } 10 \%-200 \mathrm{mln} \text {. }\end{array}$ \\
\hline $\begin{array}{l}\text { Hewitt } \\
\text { Associates }\end{array}$ & $\begin{array}{l}\text { Incomes, share values, } \\
\text { amount of sales, level of } \\
\text { clients' satisfaction, } \\
\text { doubled number of } \\
\text { competitive applications } \\
\text { for vacancies }\end{array}$ & $\begin{array}{l}\text { At enterprises with higher involvement of employees, annual } \\
\text { profits are higher by } \$ 3800 \text { per employee; share value - by } \\
12 \% \text {; annual sales - by } \$ 27000 \text { per employee; level of clients' } \\
\text { satisfaction - by } 5-10 \% \text {; the number of competitive } \\
\text { applications for vacancies has doubled. }\end{array}$ \\
\hline $\begin{array}{l}\text { Metta } \\
\text { Krebtri }\end{array}$ & $\begin{array}{l}\text { Labour productivity, } \\
\text { sales, accidents at } \\
\text { working } \\
\text { from work, staff turnover }\end{array}$ & $\begin{array}{l}\text { At enterprises with higher involvement of employees, } \\
\text { productivity is higher by } 17 \% \text {; sales - by } 20 \% \text {; accident rate } \\
\text { dropped by } 70 \% \text {; absences and sick leaves - by } 41 \% \text {; staff } \\
\text { turnover - by } 59 \% \text {. }\end{array}$ \\
\hline Gallup & Losses & $\begin{array}{l}\text { Annual losses due to involvement of employees of American } \\
\text { companies make from } \$ 272 \text { bln to } \$ 340 \text { bln. The greatest } \\
\text { losses are caused by decreased labour productivity and quality } \\
\text { of client service. }\end{array}$ \\
\hline
\end{tabular}

Source: compiled by the authors on the basis of [9].

Table 2. Steps aimed at enhancing personnel economic security aimed at enhancing personnel economic security

\begin{tabular}{|l|l|c|}
\hline \multicolumn{1}{|c|}{ Company } & \multicolumn{1}{|c|}{ Steps } & Amount \\
\hline \multirow{2}{*}{ Huddle } & Bonuses for joining a company & $£ 5000$ \\
\cline { 2 - 3 } & Annual bonuses irrespective of activity results & $£ 500$ \\
\hline TransferWise & Paid annual leave & Individually \\
\hline Airbnb & Journey pay & $\$ 2000$ \\
\hline PwC & students' loan pay & $\$ 1200$ \\
\hline Twilio & $\begin{array}{l}\text { Provision with free electronic books Kindle and financing training } \\
\text { materials }\end{array}$ & $\$ 30$ per month \\
\hline Google & $\begin{array}{l}\text { Free meals for all employees during their working hours; surcharges } \\
\text { after their spouse's death }\end{array}$ & $\begin{array}{c}50 \% \text { of salary during } \\
\text { next 10 years }\end{array}$ \\
\hline
\end{tabular}

Source: compiled by the authors on the basis of [12].

Amounts of these social expenditures are not stable or fixed, they are determined by company managers and have no threshold values. Instead, from the viewpoint of the personnel, social payments of their enterprise are a source of satisfying their own economic interests. Their amounts can be compared with threshold values (i.e. similar indicators at other enterprises of the industry as well as those average at similar enterprises in their country and in other countries, etc.). Significant changes for the worse provoke decrease of economic security of the personnel Thus, we suggest calling deviations of actual amounts of social payments from their threshold values pending and using them as key indicators for assessing personnel economic security.

Considering the fact that social expenditures that are separate items of expenditures for an enterprise are indicators of economic security of the personnel, there occurs a zone of a conflict between reaching a better level of economic security of the enterprise itself (as a legal entity without stakeholders) and that of the personnel (Fig. 2) while ensuring economic security of the enterprise.

So, the results of economic security assessment should take into account the level of security of both staff interests and the personnel.

Next, let us consider other differences between economic security of personnel interests and that of the personnel within the system of economic security of an enterprise (Fig. 3).

Thus, assessment values are the basic difference that influences the technique of assessing personnel interests and personnel security. When determining indicators of security of staff interests of an enterprise, it is reasonable to focus on the content 
which we take as the basis of economic essence of this type of security: serving economic interests of an enterprise in terms of efficient use of the personnel and the level of the personnel provision.

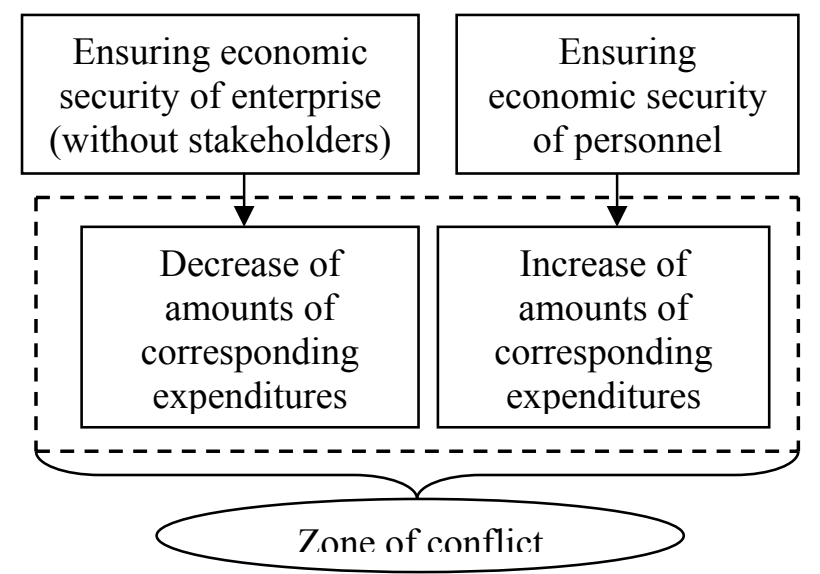

Fig. 2. The zone of conflict as an additional determinant of differentiating security of staff interests of an enterprise (as a component of economic security of an enterprise itself) and economic security of its personnel (developed by the authors)

At that, many of the known coefficients of the personnel state and movement used in analyzing labour resources and scientific works on personnel security appear to be irrelevant. In particular, we consider indicators of the personnel training level and their education degree according to positions held to be insufficiently significant when assessing staff interests security and its components at operating industrial enterprises at the current stage as issues of the kind (required education, qualification, experience etc.) are settled during recruiting and selecting for vacancies. This kind of recruitment and selection is rather deliberate and makes part of the established personnel policy of an enterprise. It provides for consideration of a required package of documents of an applicant, an interview and testing. For instance, the standard "Staff Records Management" is effectively used at Kryvbass mining and processing enterprises. Managers of structural subdivisions send job requisitions to HR departments according to this standard if additional personnel is required. Applicants who are employees of the enterprises and have allied professions are prioritized.

Thus, we consider labour productivity and profitability of spending on the personnel to be the most expedient indicators of security of efficient use of the personnel. When determining earnings deficit resulted from non-reaching a liminal value of labour productivity, a liminal (minimum necessary) output volume should be first assessed.

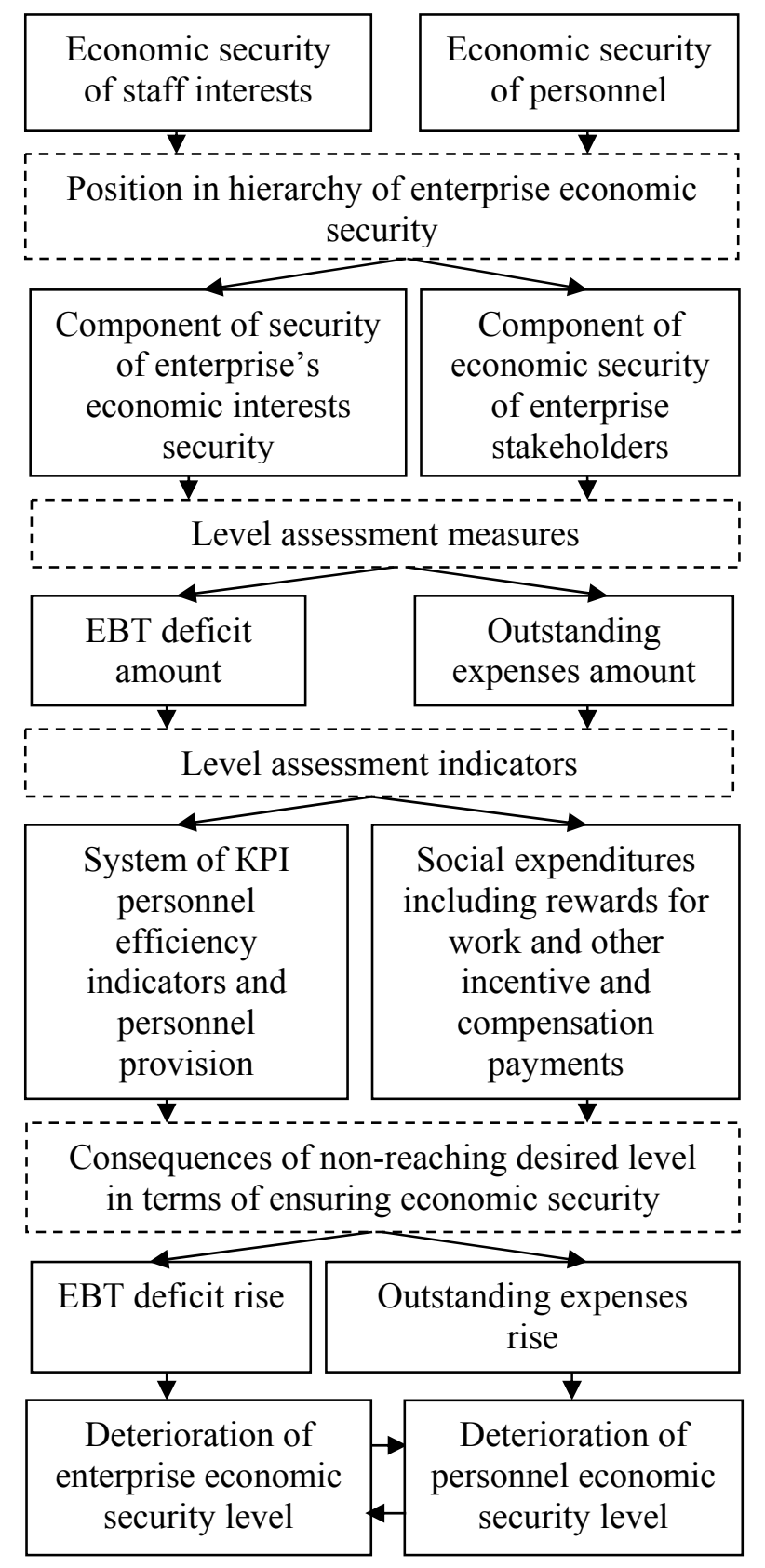

Fig. 3. Differences between economic security of staff interests and that of the personnel within the system of economic security of an enterprise (developed by the authors)

At that, the designed enterprise capacity should be considered: the liminal output volume determined on the assumption that liminal labour productivity is maintained should not be higher:

if $V l<V l p r$ then $V l=L(L P r) \times N w \phi$,

if $\mathrm{Vl} \geq V$ lpr then $V l=V$ lpr ;

where $V l$ is a liminal value of the output volume obtained at the liminal labor productivity value, c.u.; 
$L(L P r)$ is the liminal value of labour productivity determined as industry average for the assessment period, c.u.;

$N w$ is the actual number of employees, pers.;

$\mathrm{Vlpr}$ is the output volume equal to the designed capacity, c.u.

When assessing the liminal output, the product mix should be taken into account as various capacities are established for various products.

Generally, the liminal output volume exceeding the actual one (i.e. $\mathrm{Vl}>\mathrm{Va}$ ) may result in corresponding proportional excess of conditionally variable costs, the amount of which is determined as follows:

$$
\Delta C V C(V)=V C a-\sum_{j=1}^{m} V l \times V C u j,
$$

where $\triangle C V C(V)$ is excess of conditionally variable costs caused by non-reaching the liminal value of labour productivity, c.u.;

$V a$ is the actual volume of output for the assessment period, c.u.;

$j$ is the counting number of a product type at an enterprise;

$m$ is the total quantity of products types of an enterprise, units;

$V C u j$ is the amount of unit conditionally variable costs of the $j$-th product type, c.u.

Thus, applying the earlier used approach according to which the excess amount of unit conditionally variable costs corresponds to the marginal revenue and the income, EBT deficit resulted from non-reaching the liminal value of labour productivity $(\triangle E B T(L P r))$ is determined as follows:

$$
\triangle E B T(L P r)=\triangle C V C(V) \text {. }
$$

Along with that, considering wide application of the KPI-based approach to labour remuneration, other indicators may be used instead of labour productivity. KPI indicators are also expedient when it is necessary to consider specific character of an enterprise itself, its structural subdivisions, specificity of labour of certain categories of the personnel etc.

Personnel costs play an important role in the structure of enterprises' expenditures. From our point of view, their economic essence is related very much to spending on efficient functioning of IT systems. This means that, unlike most types of expenses reduction of which is prioritized in the policy of their management, spending of this type should be treated as capital investment that are to generate certain results both in the current and strategic periods. In its turn, such approach means that this one-sided "mindless" reduction of spending on the personnel (and IT expenses as well) may theoretically lead to increase in the income amount in the short-term period. But in practice, the result is opposite due to a chain reaction in the form of decreased labour productivity, etc. That is why, personnel costs should be treated in the context of efficiency of their accomplishment, personnel costs profitability being an example of this.

At first glimpse, due to a lower actual value of personnel costs profitability (Rcpa) as compared with the liminal (industry average) one, i.e. when $L(R c p)>R c p a$, the EBT deficit amount might be easily assessed:

$\Delta \mathrm{EBT}(R \mathrm{cp})=(L(R c \mathrm{p})-R c \mathrm{pa}) \times C P a$,

where $\triangle E B T(R c p)$ is deficit of the EBT value resulted from the lower than industry average profitability of personnel costs, c.u.;

$L(R c p)$ is the liminal value of personnel costs profitability which is its industry average for the assessment period, fraction units;

$\mathrm{CPa}$ is the actual amount of personnel costs, c.u.

However, to determine the level of this type of security, the liminal EBT value should be found (on the assumption personnel costs profitability equals the industry average):

$$
\mathrm{EBT}(R \mathrm{cp}) l=L(R c \mathrm{p}) \times \mathrm{CP} a \text {, }
$$

In this connection, EBT deficit may be assessed as the difference between the liminal and the actual values of the income:

$$
\Delta \mathrm{EBT}(R c \mathrm{p})=\operatorname{EBT}(R c \mathrm{p}) l-\mathrm{EBT} a,
$$

where $\triangle E B T(R c p)$ is the EBT deficit value resulted from lower than industry average profitability of personnel costs, c.u.;

$E B T(R c p) l$ is the liminal EBT value obtained on the assumption that personnel costs profitability equals its li(m)inal value, c.u.;

$E B T a$ is the actual EBT amount, c.u.

Thus, the EBT deficit amount by security of efficient use of the personnel is determined from the expression:

$\triangle E B T(S E P U)=\max \{\triangle E B T(L P r) ; \quad \Delta E B T(R c p)\}$, (8)

where $\triangle E B T(S E P U)$ is the EBT deficit amount by security of efficient use of the personnel, c.u.;

$\triangle E B T(L P r)$ is the EBT deficit amount resulted from non-reaching the liminal value of labour productivity, c.u.

The level of personnel provision is an important indicator when assessing staffing security. At present, because of increased labour migration, mostly that of blue collars, industrial enterprises face personnel shortage which impacts negatively dynamics of economic performance (from reduced production values to decreased income values).

Insufficient quantity of employees affects the output volume. To calculate EBT deficit, formulas 1-2 may be applied but the value of employee 
deficit should be used instead of their actual quantity and the actual labour productivity at the liminal value of the personnel quantity should be used instead of the liminal labour productivity. It is reasonable to use the values provided by the planning department of an enterprise as the liminal value of the personnel quantity.

Personnel provision security and efficient personnel use security are integrated into security of enterprise staff interests. By this component, EBT deficit is determined as the maximum value of the following ones:

$\triangle E B T(S I S)=\max \{\triangle E B T(S P P) ; \triangle E B T(S E P U)\},(9)$

where $\triangle E B T(S I S)$ is the EBT deficit amount by staff interests security, c.u.;

$\triangle E B T(S P P)$ is the EBT deficit amount by security of personnel provision, c.u.;

$\triangle E B T(S E P U)$ is the EBT deficit amount by security of efficient use of the personnel, c.u.

Thus, we suggest determining the security level $(L v(S I S))$ as follows:

$$
L v(S I S)=1-\frac{\Delta \operatorname{EBT}(S I S)}{\operatorname{EBT}(S I S) l},
$$

where $E B T(S I S) l$ is the liminal EBT value that is assessed through adding the earlier determined deficit value $(\triangle E B T(S I S))$ to the actual EBT amount, c.u.

It is not always reasonable to choose industry average values as liminal ones as suggested above. Depending on the analysis objective, they may be represented by the largest and/or smallest values of corresponding measures (indicators).

We find it necessary to pay attention to the gradation of levels of economic security and its components under study. Such gradation most frequently represents a gradual transition from the worst level to the best one (or vice versa). At that, as a rule, after the worst level scientists start singling out danger and its corresponding levels. This approach is visualized in Fig. 4 where attention is focused on the approach to understanding the "security - danger" transition and not on the manes of the singled out levels (which are chosen randomly).

However, the above approach does not seem sufficiently substantiated. Even the visualization enables stating that the catastrophic level of security (whatever names they have: minimum, critical, etc.) approaches the low level of danger if not equals it [14]. The most reasonable take on differentiation of security levels is the one according to which an enterprise enter the danger zone when security reaches the low level (Fig. 5).

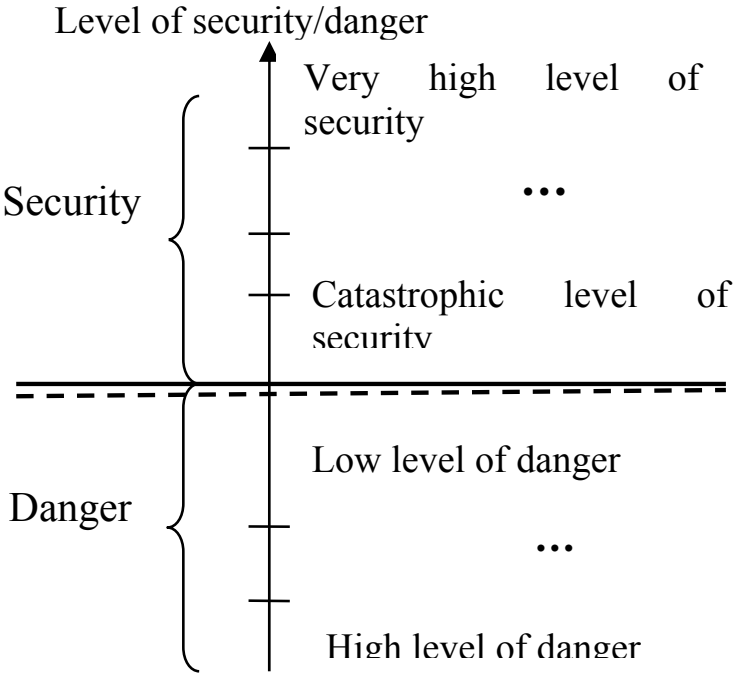

Fig. 4. The most common approach to gradation of levels of economic security and its individual components (developed by the authors on the basis of generalization of the most typical gradations of economic security levels)

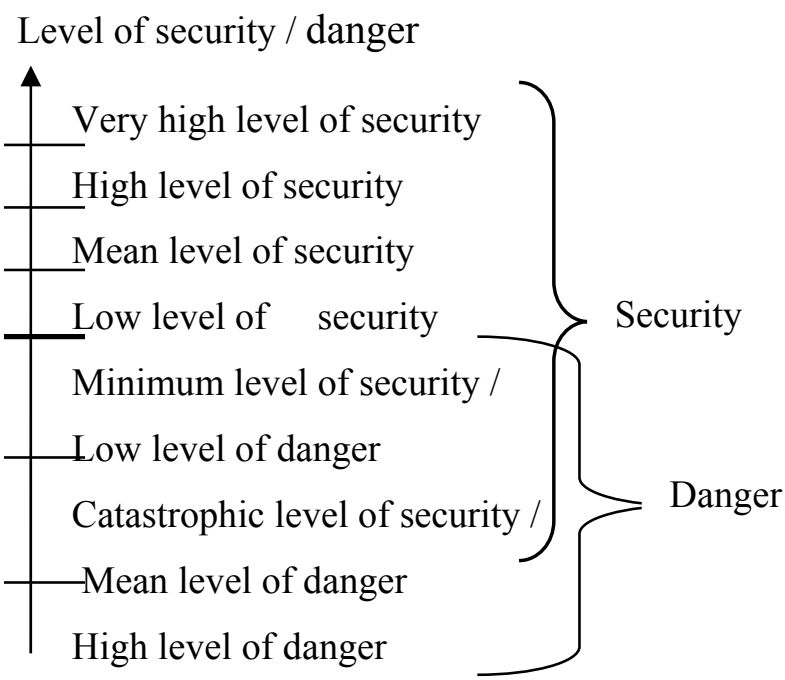

Fig. 5. The author's approach to gradation of levels of economic security and its individual components (developed by the authors)

Thus, the closer to one the obtained value of the personnel interests security level $(L v(S I S))$ is, the higher the personnel interests security level is:

- at $L v(S I S)<0$ - the high level of the staff interests security;

- at $L v(S I S)=0$ - the catastrophic level of the staff interests security (which is the same as the mean level of danger);

- at $0<L v(S I S)<0.25$ - the minimum level of the staff interests security (which is the same as the low level of danger;

- at $0.25 \leq L v(S I S)<0.5$ - the low level of the staff interests security; 
- at $0.5 \leq L v(S I S)<0.75$ - the mean level of the staff interests security;

- at $0.75 \leq L v(S I S)<1.0$ - the high level of the staff interests security;

- $\quad$ at $L v(S I S)=1.0 \quad$ - the very high level of the staff interests security.

Let us consider expenditures for ensuring the personnel security.

When assessing their values, comparison bases should be determined. As is mentioned above, employees can compare their own salaries/wages based on various criteria. In [13, p.187], this criterion is requirements of trade union organizations. However, the European pay level seems to be the most relevant. The bright illustration is strikes of employees of the PJSC "ArcelorMittal Kryvyi Rih" which took place in 2017 and 2018. In May 2018, the employees of the railway shop of the company joined the strike of "Ukrzaliznytsia" workers. They demanded increase of their pays to the European level - $€ 1000$. Besides, they demanded to ensure compliance of the entire rolling stock conditions with the labour safety standards [15].

As regards labour safety costs, it should be noted that the current law of Ukraine on labour safety states their liminal value - not less than $0.5 \%$ of the payroll budget of the previous year. At the same time, the Industrial a/Agreement of the mining and metallurgical complex of Ukraine for 2011-2012 (which is still valid as according to the current legislation it is valid until a new agreement is concluded) this value makes $0.6 \%$ of the sales [13, p.187]. At that, in the EU countries there are no such financial practices. Instead, there are established security levels that are to be observed. Basic standard labour safety costs can be found in clause/Clause 10 of the Health and Safety at Work Act of the Russian Federation, according to which their value is established at the level on not less than $0.1 \%$ of the amount of production costs (goods, works, services). Let us consider fulfillment of the mentioned standards at the PJSC "ArcelorMittal Kryvyi Rih" (Table 3).

Table 3. Indicators of economic security of the personnel at the PJSC "ArcelorMittal Kryvyi Rih"

\begin{tabular}{|l|c|c|c|c|}
\hline \multicolumn{1}{|c|}{ Years } & 2015 & 2016 & 2017 & 2018 \\
\hline Actual average pay per lemployee, UAH & 9028.58 & 10266.52 & 13436.43 & 13735.6 \\
\hline $\begin{array}{l}\text { €1000 in UAH equivalent (average annual rate according } \\
\text { to data provided by National Bank of Ukraine) }\end{array}$ & 24228.7 & 28291.9 & 30004.2 & 32142.9 \\
\hline $\begin{array}{l}\text { Deviation of actual average pay from the desired one, } \\
\text { UAH }\end{array}$ & 15200.12 & 18025.38 & 16567.77 & 18407.3 \\
\hline Actual payroll budget, 000 UAH & 2594003 & 2567863 & 3124777 & 3422306.7 \\
\hline $\begin{array}{l}\text { Actual spending of labour safety and health and safety } \\
\text { measures, 000 UAH }\end{array}$ & 252000 & 278300 & 316700 & 396200 \\
\hline $\begin{array}{l}\text { Actual spending on labour safety in the current year, \% of } \\
\text { previous year }\end{array}$ & - & 10.73 & 12.33 & 12.68 \\
\hline Actual sales value (earnings), 000 UAH & 46261289 & 52961756 & 66185876 & 67963171 \\
\hline Actual spending on labour safety, \% of \% of previous year & 0.54 & 0.53 & 0.48 & 0.58 \\
\hline Actual amount of production costs, 000 UAH & 45141096 & 47924608 & 56562119 & 54675902 \\
\hline Actual spending on labour safety, \% of production costs & 0.56 & 0.58 & 0.56 & 0.72 \\
\hline
\end{tabular}

Source: developed by the authors on the basis of the official information of the PJSC "ArcelorMittal Kryvyi Rih" [15]

The calculations enable the conclusion that there exists a significant gap between the desired and actual salaries/wages. At that, the PJSC "ArcelorMittal Kryvyi Rih" fulfilled all possible standards of spending on labour safety except for those stipulated in the Industrial agreement of the mining and metallurgical complex of Ukraine for 2011-2012. It should be noted that the company employees are not satisfied with certain aspects of labour safety and this resulted in the strike of 2018. Besides, there occur some occupational injuries. Therefore, it is reasonable to use the standard of the above mentioned Agreement as the preliminary value [16]. This means that to assess the level of

labour security as a component of economic security of the personnel, it is necessary to compare the amount that could appear if the Industrial agreement was observed with corresponding actual expenses [17]. The determined difference makes the amount of outstanding expenses by labour safety security.

Expenses on culture, sporting activities, health promotion, work with children, maintenance and servicing of social and cultural facilities are other important cost items. The standard of their minimum amount can be found in the Industrial agreement between the State Service of Ukraine for emergencies and trade unions of employees of governmental institutions of Ukraine and workers of 
the mining and metallurgical complex of Ukraine for 2017-2020. According to this agreement, the above standard is established at the level not less than $0.3 \%$ of the pay budget.

As regards the spending on the personnel, it should be noted that $[13$, p.188] suggests using $2 \%$ of the pay budget as a standard value which is reflection of foreign companies' practices. Let us compare: in 2018 expenses on training the personnel of the PJSC "ArcelorMittal Kryvyi Rih" made 14300 thousand UAH [15] which was $0.42 \%$. Therefore, when financing personnel training there also occur outstanding expenses.

Thus, we suggest determining the level of economic security of the personnel according to the formula:

$$
L v(S)=1-\frac{\Delta E O(S p)}{\text { SocEl }},
$$

where $\triangle E O(S p)$ is the value of outstanding expenses as the difference between their liminal value (minimum required amount determined according to standards) and the actual amount of social expenses, c.u.;

SocEl is the liminal amount of social expenses (salaries/wages and other spendings: on training, labour safety, various social events) determined as the total of actual expenses and their outstanding value, c.u.

To interpret the obtained values, it is reasonable to apply the gradation in Fig. 5 and corresponding numerical interpretations.

To assess economic security of an enterprise, the obtained indications by security of staff interests of an enterprise and personnel security should be incorporated into one indicator. So, we suggest obtaining the level of security $(\operatorname{Lv}(S))$ from the expression:

$$
L v=1-\frac{\Delta \mathrm{EBT}(d)+\Delta \mathrm{EBT}(S \mathrm{IS})+\Delta E \mathrm{O}(\mathrm{Sp})}{\mathrm{EBT} l}
$$

where $\triangle E B T(d)$ is the deficit of EBT determined by other components of economic security besides staff interests, c.u.;

$\triangle E B T(S I S)$ is the deficit of EBT by security of enterprise staff interests, c.u.;

$E B T l$ is the liminal value of EBT determined as the total of the actual value and deficit of EBT by all the components of economic security of an enterprise, c.u.

To interpret the obtained values, it is reasonable to apply the above scale.

\section{Conclusion}

Thus, the determined differences in indicators of assessing economic security of the personnel and staff interests security enable enhancement of their assessment methods. In particular, the methods of assessing staff interests security is based on determining the value of earnings before tax deficit which an enterprise may obtain in case of nonreaching indicators if efficient use of the personnel and ensuring their minimum necessary values. Through the example of the PJSC "ArcelorMittal Kryvyi Rih", it is substantiated that insufficient financing of social programs is characterized by outstanding expenses of an enterprise, the rise of which affects economic security of its personnel and increases the threats caused by them. There are suggested methods of simultaneous consideration of values of earnings before tax deficit and outstanding expenses in measuring the level of economic security of an enterprise. Application of the suggested approach will contribute to a more effective control over the level of economic security and improve the analytical support of making managerial decisions of the financial and economic nature.

\section{References:}

[1] Nusinova O. V., Molodetska O. M., Comprehensive assessment of socio-economic security of enterprises. Dionis, 2011.

[2] Demidova N., Akilina O., Kirzhetska M., Lagovskyi V., Besarab S., Accumulation and fulfilment of the human capital potential in order to strengthen the economic security, Journal of Security and Sustainability, No. 8(4), 2019, pp. 801-813.

[3] Markoulli M., Lee C., Byington E., Felps, W., Mapping Human Resource Management: Reviewing the field and charting future directions. Human Resource Management Review, No. 27(3), 2017, pp. 367-396.

[4] Sagiyeva R., Zhuparova A., Ruzanov R., Doszhan R., Askerov A., Ntellectual input of development by knowledge-based economy: problems of measuring in countries with developing markets, Entrepreneurship and Sustainability, No. 6(2), 2018, pp. 711-728.

[5] Shira T. B., Personal security of the employee as the basis for ensuring the economic security of the enterprise. Effective economy, No. 10, 2015,URL:http://www.economy.nayka.com.ua/ ?op=1\&z=4408 Accessed 13 Feb 2020.

[6] Zatonatskiy D., Innovation Methods and Models of Personnel Security Management: Opportunities and Imperatives of Use at Ukrainian Enterprises, Marketing and Management of Innovations, Vol. 1, 2019, pp. 294-301. 
[7] Nusinov V. Ya., Mishchuk Ie. V., Izmaylov Ya., Development of the stereometric method to the analysis of economic categories and processes and its application in security and taxation, Baltic Journal of Economic Studies, 2019, Vol. 5 (4), pp. 160 - 170.

[8] Prakash R., Garg P., Comparative assessment of hdi with composite development index (CDI), Insights into Regional Development, Vol.1(1), 2019, pp. 58-76.

[9] Gembik O., To entice and captivate: how to increase employee involvement and why it is needed, Jansen, 2020, URL: https://jansen.com.ua/zavlech-i-uvlech-kakpovysit-vovlechennost-sotrudnikov/ Accessed 13 Feb 2020.

[10] Pelster B., Schwartz D., Rizzo D., Valenzuela D., Bernard Fan der Weaver. The struggle for the development of human resources. Expanding horizons: Trends in Human Resource Development - 2013, 2013, pp. 47 50.

[11] Armstrong M., Baron A., Performance Management: Finding the Missing Pieces to Close The Intelligence Gap, Alpina Publisher Publishing House, 2020.

[12] Official site human resources and human resources community communities, URL: https:/hrliga.com/index.php?module=news\&op =view\&id=20605 Accessed 13 Feb 2020.

[13] Tevelev D.M., Nusinov V.Ya., A.V. Nusinova, Lebed I.A., Assessment of the level of reputation and corporate governance in enterprises, Chernyavsky D.O., 2013.

[14] Malyarets, L.M., Babenko, V.O., Nazarenko, O.V., Ryzhikova, N.I. The Modeling of Multicriteria Assessment Activity in Enterprise Management, International Journal of Supply Chain Management, Vol. 8, No. 4, pp. 9971004.

[15] Official site of ArcelorMittal Kryviy Rih, URL: https://ukraine.arcelormittal.com/ Accessed 13 Feb 2020.

[16] Shorikov, A.F., Babenko, V.A. (2014). Optimization of assured result in dynamical model of management of innovation process in the enterprise of agricultural production complex. Economy of Region, Issue 1, pp. 196202. doi: $10.17059 / 2014-1-18$

[17] Adamenko M., Mishchuk I., Zinchenko O., Economic security and innovation activity of personnel - determinants of sustainable development of enterprises, E3S Web Conf., No. 166, 2020, URL: https://doi.org/10.1051/e3sconf/202016613009 Accessed 22 April 2020. 